\title{
NUTRITIONAL PREFERENCES OF WOOD-FEEDING TERMITES INHABITING FLOODPLAIN FORESTS OF THE AMAZON RIVER, BRAZIL
}

\author{
Norma Cecilia Rodriguez BUSTAMANTE ${ }^{1}$, Christopher MARTIUS ${ }^{2}$
}

\begin{abstract}
The alimentary preferences of five species of wood-feeding termites of the genus Nasutitermes that coexist in the inundated forests of the floodplains of the Amazon river várzea for species of fresh wood and for wood in different stages of decomposition was evaluated in laboratory tests. Wood of low density was generally preferred; the decay stages were preferred over fresh wood. The five termite species differ in the amplitude of their choices, indicating a strong differentiation in food choice among them. Differences in feeding preferences may be a niche-separating factor for these five Nasutitermes species of the floodplains.
\end{abstract}

Key Words: Amazon River, Floodplain Forest, Termites, Wood Consumption Preference, Ecological Niche Concept.

Preferência Nutricional de Térmitas Xilófagos Colonizadores de Florestas de Ảreas Alagáveis do Rio Solimões/Amazonas, Brasil.

RESUMO - A preferência alimentar de cinco espécies de térmitas xilófagos do gênero Nasutitermes que coexistem nas florestas alagáveis da várzea do Rio Solimões/Amazonas por espécies de madeira sã e por madeira em diferentes estágios de decomposição foi avaliada em testes de laboratório. Madeira de baixa densidade foi geralmente preferida; os estágios de decomposição foram preferidas sobre a madeira sã. As cinco espécies de térmitas diferem na amplitude de sua escolha, o que indica uma diferenciaçăo forte entre ela na escolha do alimento. Estas diferenças na preferência alimentar podem ser um fator separador de nicho para as espécies de Nasutitermes da várzea.

Palavras-Chave: Rio Solimões/Amazonas, várzea, cupins, preferência de consumo de madeira, conceito do nicho ecológico.

\section{INTRODUCTION}

If apparently very similar species coexist in a given physical space, there must be at least one factor which ensures ecological separation; in the ndimensional hypervolume which represents the ecological "niche" there must be at least one dimension which differentiates the niche of one species of that of another species with which it coexists. Put more simply, "complete competitors cannot coexist", which is the principle of competitive exclusion ("Gause's law") (Deshmukh, 1986:117).

In a white-water influenced flood- plain (várzea) forest of the Amazon River near Manaus, five species of the termite genus Nasutitermes (Insecta: Isoptera: Termitidae: Nasutitermitinae) are found (Martius, 1989; 1990; 1997a) which are of similar size, behaviour, feeding and nesting habits. All are wood-feeders and live in arboreal carton nests. The species are Nasutitermes corniger, $N$. macrocephalus, $N$. ephratae, $N$. surinamensis, and $N$. tatarendae. Although interspecific aggression was observed between them (Martius, unpubl. observations), all these species coexist in the periodically inundated floodplain forest,

Universidade do Amazonas (FUA), Manaus, Brazil

2 Instituto Nacional de Pesquisas da Amazônia (INPA), Manaus, Brazil. [present address: ZEF University of Bonn, Walter-Flex-Stv.3, D-53113 Bonn, Germany.] 
where the availability of food can be very limited during the flood.

We studied the nutritional preference of these five termite species for fresh and rotten wood of different tree species. In the tests, we used wood of seven tree species which are typical of the white water floodplain forest (Junk, 1984; Martius, 1992; Worbes et al., 1992). One aim of this study was to evaluate whether feeding preference could be an effective factor of niche separation for these five termite species which otherwise differ very little.

\section{MATERIAL AND METHODS}

We used laboratory colonies consisting of 200 workers and 100 soldiers of each species, which were held in plastic cages under controlled humidity and ambient air temperatures, using vermiculite and sieved sand as substrate. The wood was offered in blocks of $3.0 \times 1.5 \times 1.5 \mathrm{~cm}$. There were nine repetitions and one control for each of the treatments. The treatments were:

1) Fresh wood: Seven blocks of fresh wood were offered to each of the termite species in separate tests, each block being from wood of a different tree species. Wood of the following tree species was used: Macrolobium acaciifolium, Salix humboldtiana, Vitex cymosa, Nectandra amazonum, Crataeva benthamii, Pseudobombax munguba, and Triplaris surinamensis.

2) Decaying wood: Blocks made from wood in four different decay stages were offered to each of the termite species separately. The decay stages were obtained by exposing the wood to decomposition in the field for $0,2,4$, or 6 months before the experiment. In this experiment, wood of the following tree species was used: $M$. acaciifolium, $V$. cymosa and $T$. surinamensis.

All the experiments lasted 30 days, after which loss of biomass (g), loss of biomass as related to initial weight $(\%)$, and damage to the wood blocks according to an arbitrary scale of damage were evaluated. Further details are given in Bustamante (1993).

\section{RESULTS AND DISCUSSION}

Three important results were obtained from these experiments:

1. The experiments with fresh wood showed that wood of low density (S. humboldtiana and P. munguba) is generally preferred by all species over wood of higher density, the linear regression between consumption (as $\%$ of initial wood weight) and wood density being negative $(\mathrm{y}=$ $22.25 x+16.51 ; r^{2}=0.51$; Fig. 1 ; upper curve). (The regression between absolute weight loss in $\mathrm{g}$ and wood density, $y=-0.05 x+0.24 ; r=0.006$, Fig. 1 lower curve, is not significant but this result should be cautiously interpreted because of the weak power of this test).

For single termite species this relationship is statistically significant only for $N$. corniger and $N$. tatarendae when relative weight loss is considered (Fig. 2; lower curves).

The five termite species differ in the amplitude of their choices (Tab, 1). N. surinamensis has the narrowest preference 
spectrum; it prefers wood of only one tree ( $S$. humboldtiana). The termites $N$. ephratae and $N$. macrocephalus prefer 2-3 out of the seven wood species offered. $N$. tatarendae chooses five out of the seven offered woods, and $N$. corniger shows no preference at all. (These assessments refer to absolute biomass loss in $\mathrm{g}$ ).

2. The trials with decaying wood showed that the decay stages $(2,4$, and 6 months of decay) were generally preferred, and fresh wood ( 0 months) was rejected (Tab. 2). The termite species showed different amplitudes in their reactions, $N$. macrocephalus and $N$. surinamensis being the most specialized species. Among the 3 woods, those with lower density were preferred (Tab. 3).

3. We found that the results vary according to the modality used for evaluation (biomass in $\mathrm{g}$, relative biomass (\%), or scale of damage - results of the scale of damage not shown here). For example, if the evaluation is made by percentage of biomass loss, the apparent choice preference for fresh wood species is different from the evaluation made by biomass in $\mathrm{g}$ (Fig. 1 and 2; upper and lower curves; Tab. 2 and 3). This is in agreement with findings of Waller et al. (1990), and affects the practical conclusions which can be drawn from such experiments, for example with respect of the resistance of different wood species to ter-

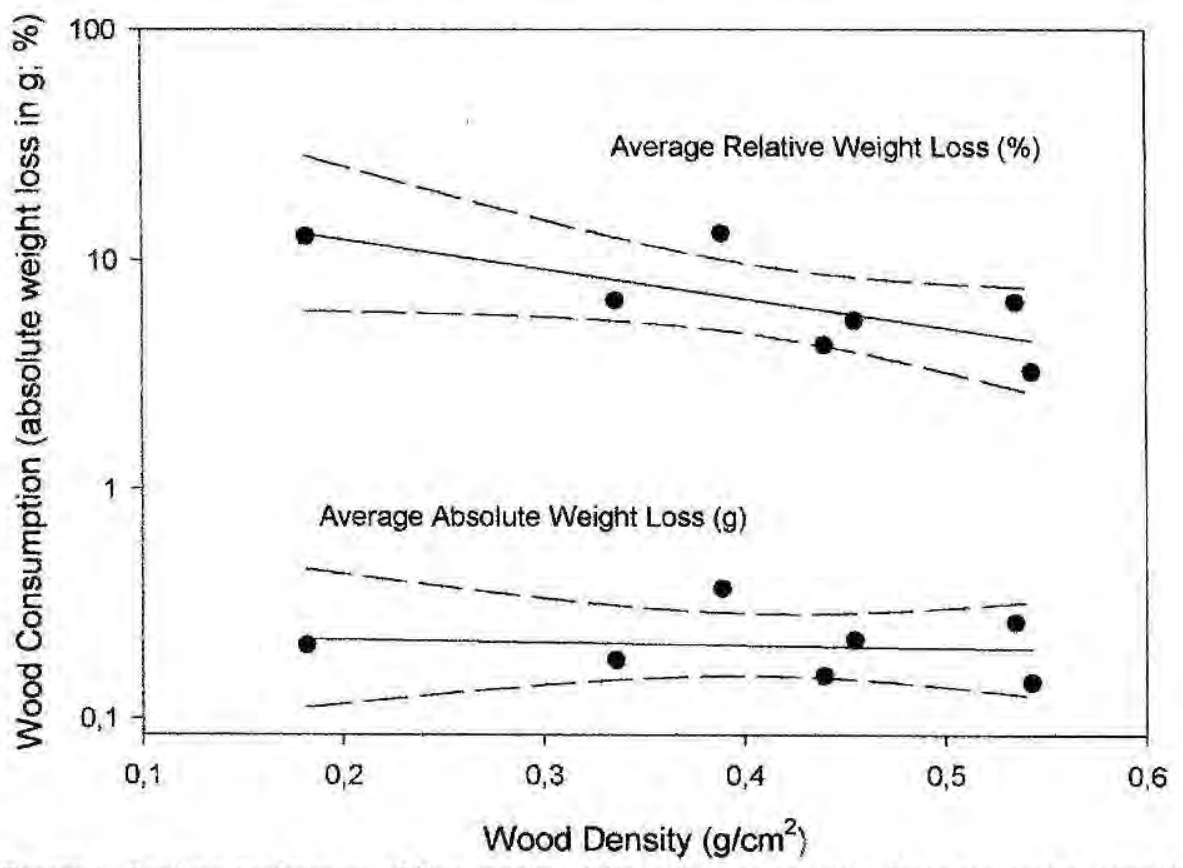

Figure 1. Feeding preferences of five species of Nasutitermes pooled. Linear regressions (straight lines) and confidence intervals (95\%; dotted lines) of wood consumption (y-axis; average absolute weight loss of wood mass in $\mathrm{g}$, below; average relative weight loss in \%, above) and wood density ( $x$-axis). For statistical significance of regressions see text. The points show the average results for single wood species. 


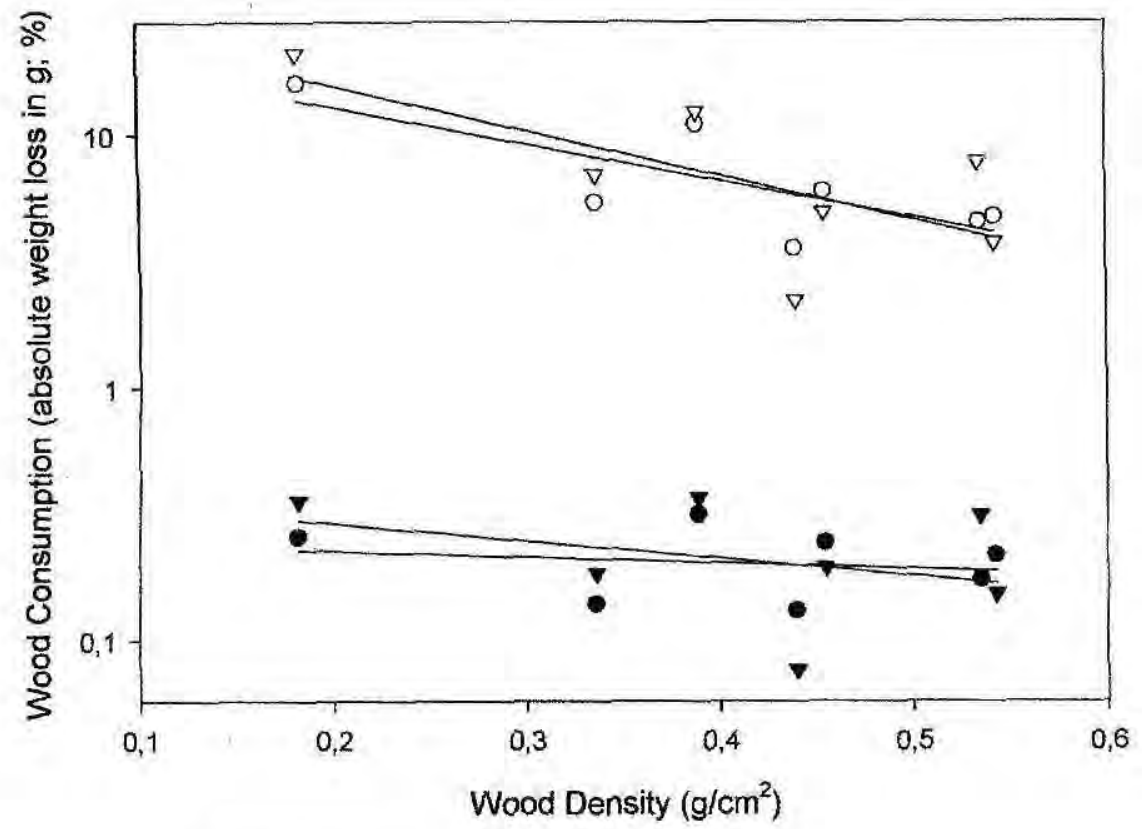

- N. corniger: Absol. Wt. Loss

O N. corniger: Rel. Wt. Loss (\%)

$\checkmark$ N. tatarendae: Absol. Wt. Loss

$\nabla N$. tatarendae: Rel. Wt. Loss (\%)

Linear Regressions

Figure 2. Feeding preferences of Nasutitermes corniger and Nasutitermes tatarendae. Linear regressions of wood consumption ( $\mathrm{y}$-axis; average absolute weight loss of wood mass in $\mathrm{g}$, below; average relative weight loss in \%, above) and wood density (x-axis). The points show the average results for single wood species. The regressions of relative weight loss are statistically significant; of absolute weight loss they are not significant.

mite attack and identification of "termite resistant" wood to be recommended for construction, very common in the literature (cf. Wolcott, 1957; SchultzeDewitz, 1960; Sen-Sarma \& Chatterjee, 1968; Santos, 1982; Supriana, 1988).

\section{CONCLUSION}

About 400 different tree species are found in floodplain forests (Junk, 1989; Worbes et al., 1992). Different pieces of dead wood in the varzea are subject to very different decay histo- ries: standing and lying dead wood is subject to different moisture regimes (Swift, 1977). Logs which are subject to intermittent aquatic and terrestrial decay degrade faster than logs subject only to terrestrial decay; the latter degrade much faster than submerged logs, a fact which is important in floodplains (Martius, 1997b). Differential attack of fungus and insects or only insects and microclimatic differences between the upper and lower side of a lying trunk lead to compart- 
Table 1. Significant consumption preferences for fresh wood of 7 tree species by Nasutitermes species (5 species pooled) of the várzea floodplains. Wood species are arranged according to increasing density (cf. Fig. I). An X indicates those wood species on which consumption (measured as absolute weight loss in g) was significantly different from the others. Specific wood density of trees from Bustamante (1993).

\begin{tabular}{|c|c|c|c|c|c|c|c|}
\hline \multirow[b]{2}{*}{ Termite species } & \multicolumn{7}{|c|}{ Tree species (Specific density in $\mathrm{g} \mathrm{cm}^{3}$ ) } \\
\hline & $\begin{array}{l}\text { Pseudo- } \\
\text { bombax } \\
\text { munguba } \\
(0.182)\end{array}$ & $\begin{array}{c}\text { Macrolobium } \\
\text { acaciifolium } \\
\qquad(0.336)\end{array}$ & $\begin{array}{c}\text { Salix } \\
\text { humboldtiana } \\
(0.389)\end{array}$ & $\begin{array}{c}\text { Triplaris } \\
\text { surinamensis } \\
(0.440)\end{array}$ & $\begin{array}{l}\text { Crataeva } \\
\text { benthamii } \\
(0.455)\end{array}$ & $\begin{array}{c}\text { Vitex } \\
\text { cymosa } \\
(0.535)\end{array}$ & $\begin{array}{c}\text { Nectandra } \\
\text { amazonum } \\
(0.543)\end{array}$ \\
\hline N.corniger & $x$ & $x$ & $x$ & $x$ & $x$ & $x$ & $x$ \\
\hline N.macrocephalus & & $x$ & & & $x$ & $\mathrm{x}$ & \\
\hline N.ephratae & & & $\mathrm{x}$ & & & $\mathrm{X}$ & \\
\hline N.surinamensis & & & $x$ & & & & \\
\hline N.tatarendae & $x$ & $x$ & $x$ & & $x$ & $\mathrm{X}$ & \\
\hline
\end{tabular}

Table 2: Significant consumption preferences for decaying wood of three tree species (cf Table 3) in four stages of decay $(0,2,4$, and 6 months of decay) by Nasutitermes species of the várzea floodplains. All wood species pooled. An X indicates wood of decay stages on which termites fed significantly more than on the others.

\begin{tabular}{|c|c|c|c|c|}
\hline \multirow[b]{2}{*}{ Termite species } & \multicolumn{4}{|c|}{ Decay Stages (Months of Decay) } \\
\hline & 0 & 2 & 4 & 6 \\
\hline \multicolumn{5}{|c|}{ Absolute Weight Loss $(g)$} \\
\hline N.corniger & & $x$ & $x$ & $x$ \\
\hline N.macrocephalus & & $x$ & & \\
\hline N.ephratae & & $x$ & $x$ & $x$ \\
\hline N.surinamensis & & $\mathrm{x}$ & & \\
\hline N.tatarendae & $x$, & $x$ & $x$ & $x$ \\
\hline \multicolumn{5}{|c|}{ Relative Weight Loss (\%) } \\
\hline N.corniger & & & $x$ & $x$ \\
\hline N.macrocephalus & & $x$ & & \\
\hline N.ephratae & & $x$ & $x$ & $x$ \\
\hline N.surinamensis & & $x$ & $x$ & $x$ \\
\hline N.tatarendae & & $x$ & $\mathrm{x}$ & $x$ \\
\hline
\end{tabular}

Table 3. Significant consumption preferences for decaying wood of three tree species in four stages of decay (cf.Table 2) by Nasutitermes species of the varzea floodplains. Wood species are arranged according to increasing stage of decay, An X indicate wood on which termites fed significantly more than on the others (all decay stages pooled).

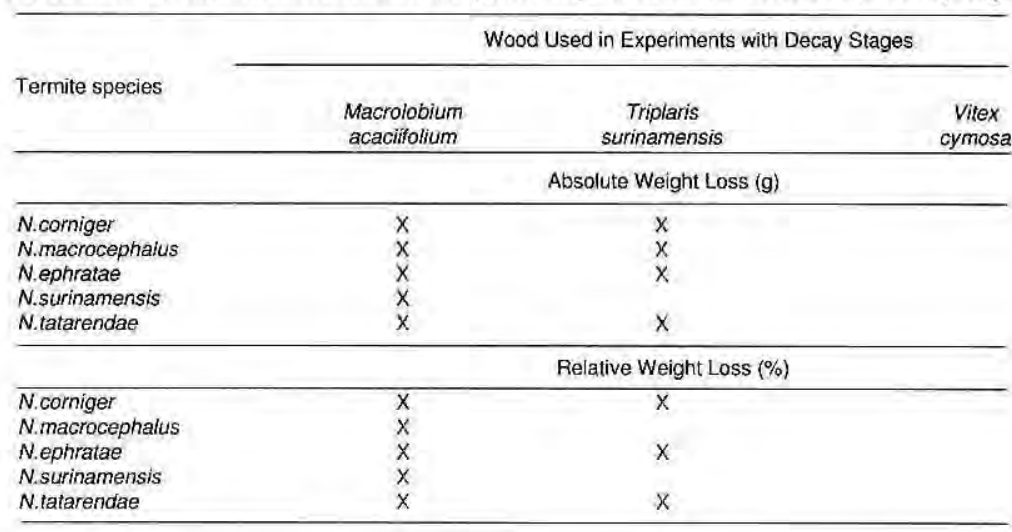


mentalization of decay (Shigo \& Marx, 1977). All these phenomena, together with the high tree species diversity, lead to a wide variety of decay stages being offered to xylophagous insects at any moment in the forest. The seven tree species and four distinguishable decay stages which were offered in the laboratory experiment are certainly not representative of the wide variation of food quality encountered in the field by termites.

Very likely, therefore, the "real" food choices of termites in the field are far different from the preferences recorded in laboratory experiments. Nevertheless, we conclude that a strong differentiation in food choice exists between these 5 termite species which live in the varzea. This could explain their coexistence in várzea areas. The separation of food niches impedes interspecific competition for food and thus allows overlap of foraging territories. Thus, differences in feeding preference may well be one of the major factors which leads to the effective separation of the 5 Nasutitermes species occurring in the varzea.

\section{ACKNOWLEDGEMENTS}

This work was funded by the MaxPlanck-Institut für Limnologie (Tropical Ecology Working Group), Plön, Germany, by the Gesellschaft für Technische Zusammenarbeit (GTZ, Eschborn; Contract No. 4-3001-60098130), and the Deutsche Forschungsgemeinschaft (DFG, Bonn, Germany: Project No. Ma 1276/21 "Termites and tropical diversity"). The study is a result of the German-Brazilian research cooperation (Projeto INPA/MaxPlanck). N.C.R.B. received a grant from the Conselho Nacional de Pesquisas (CNPq), Brasília, Brazil. We are greatly indebted to J. Camilo Guerrero Hurtado, INPA (Pós-Graduaçẫo), for his help with the statistical analysis of the data. We thank Neliton Marques da Silva and Joana D'Arc Ribeiro, both University of Amazonas, Manaus, for their critical revision of this manuscript.

\section{Literature cited}

Bustamante, N.R.C. 1993. Preferências alimentares de 5 espécies de cupins Nasutitermes Dudley, 1890 (Termitidae: Isoptera) por 7 espécies de madeiras da värzea na Amazônia Central. Tese de Mestrado, INPA/FUA, Manaus, 151 p.

Deshmukh, I. 1986. Ecology and tropical biology. Blackwell Scientific Publications, Palo Alto, $387 \mathrm{p}$.

Junk, W. J. 1984, Ecology of the várzea floodplain of Amazonian white-water rivers. In: H. Sioli (ed.): The Amazon. Limnology and landscape ecology of a mighty tropical river and its basin. Dr. W. Junk Publishers, Dordrecht, 215-243.

Junk, W. J. 1989. Flood tolerance and tree distribution in Central Amazonian floodplains In: Tropical Forests. Academic Press, New York: 47-64.

Martius, C. 1989. Untersuchungen zur Ökologie des Holzabbaus durch Termiten (Isoptera) in zentralamazonischen Überschwemmungswäldern (Várzea). AFRA-Verlag, Frankfurt am Main: 285 p.

Martius, C. 1990. The influence of geophagous termites on soils of inundation forests in Amazonia - First results. In: Veeresh, G. K., Mallik, B., Viraktamath, C. A. (eds.). Social Insect and the Environment. Oxford \& IBH Publishing Co., New Delhi: 209-210.

Martius, C. 1992. Density, humidity, and nitrogen content of dominant wood species of floodplain forests (várzea) in 
Amazonia. Holz als Roh-und Werkstoff, 50: 300-303.

Martius, C. 1997a. The Termites. In: W. J. JUNK (ed.). The Ceniral-Amazonian floodplain: ecology of a pulsing system. Ecological Studies 126, Springer-Verlag, Berlin: 361-371

Martius, C. 1997b. Decomposition of Wood. In: W. J. Junk (ed.). The Central-Amazonian floodplain: ecology of a pulsing system. Ecological Studies 126 , Springer-Verlag, Berlin: 267-276

Santos, M.D.G.C. 1982. The susceptibility of 35 Amazon wood species to Cryptotermes brevis (Walker). 13th Annual Meeting of International Research Group of Wood Presenation, Document IRG/WP/1160, $11 \mathrm{p}$.

Schultze-Dewitz, G. 1960. Form und Intensität des Termitenangriffes an Hölzern verschiedener Struktur und Rohwichte. 1 Mitt: Prufungen von getrenntem Frühund Spätholz. HoIz als Roh- und Werkstoff, 18: 365-367.

Sen-Sarma, P.K.; Chatterjee, P.N. 1968. Studies on the natural resistance of timbers to termite attack. V. Laboratory evaluation of the resistance of three species of Indian wood to Microcerotermes beesoni Snyder (Insecta: Isoptera: Termitidae). Indian For, 94: 694-704.
Shigo, A. L., Marx, H, G. 1977. Compartmentalization of decay in trees U.S. Dep. Agric. Tech. Bull., 405: 1-73.

Supriana, N. 1988. Studies on the natural durability of tropical timbers to termite attack. International Biodeterioration, 24: 337-341.

Swift, M. J. 1977. The ecology of wood decomposition. Sci Prog. (Oxf), 64: 175-199.

Waller, D. A., Jones, C. G., Lafage, J. P. 1990. Measuring wood preference in termites. Entomologia Experimentalis et Applicata, 56(2): 117-123.

Wolcott, G.N. 1957. Inherent natural resistance of wood to the attack of the West Indian termite Copptotermes brevis Walker. J. Agric. Univ. Pueno Rico, 41; 259-311.

Worbes, M., Klinge, H., Revilla, J. D., Martius, C. 1992 . On the dynamics, floristic subdivision and geographical distribution of várzea forests in Central Amazonia. Journal of Vegetation Science, 3: 553-564. 